Article

\title{
Treatment of Gaseous Ammonia Emissions Using Date Palm Pits Based Granular Activated Carbon
}

\author{
Muhammad Vohra \\ Environmental Engineering Program, Civil and Environmental Engineering Department, King Fahd University \\ of Petroleum \& Minerals (KFUPM), Dhahran 31261, Saudi Arabia; vohra@kfupm.edu.sa; Tel.: +966-013-860-2854
}

Received: 3 February 2020; Accepted: 18 February 2020; Published: 27 February 2020

check for updates

\begin{abstract}
The present work investigated the application of granular activated carbon (GAC) derived from date palm pits (DPP) agricultural waste for treating gaseous ammonia. Respective findings indicate increased breakthrough time (run time at which $5 \%$ of influent ammonia is exiting with the effluent gas) with a decrease in influent ammonia and increase in GAC bed depth. At a gas flow rate of $1.1 \mathrm{~L} / \mathrm{min}$ and GAC column length of $8 \mathrm{~cm}$, the following breakthrough trend was noted: $1295 \mathrm{~min}(2.5 \mathrm{ppmv})>712 \mathrm{~min}(5 \mathrm{ppmv})>532 \mathrm{~min}(7.5 \mathrm{ppmv})$. A qualitatively similar trend was also noted for the exhaustion time results (run time at which $95 \%$ of influent ammonia is exiting with the effluent gas). The Fourier Transform Infrared Spectroscopy (FTIR) findings for the produced GAC indicated some salient functional groups at the produced GAC surface including $\mathrm{O}-\mathrm{H}, \mathrm{C}-\mathrm{H}, \mathrm{C}-\mathrm{O}$, and $\mathrm{S}=\mathrm{O}$ groups. Ammonia adsorption was suggested to result from its interaction with the respective surface functional groups via different mechanisms. Comparison with a commercial GAC showed the date palm pits based GAC to be having slightly higher breakthrough and exhaustion capacity.
\end{abstract}

Keywords: ammonia gas; adsorption; date palm pits; activated carbon

\section{Introduction}

An exponential increase both in the human population and related industrial activities, specifically in the past century, has caused a significant increase in air pollution. Consequently several stringent environmental regulations have been promulgated, which do require an appropriate treatment of gaseous emissions, including ammonia $\left(\mathrm{NH}_{3}\right)$, considering the respective toxicity and environmental concerns [1-3]. Gaseous ammonia is typically emitted from several sources including fertilizer industry [4], wastewater treatment plants [2,5], agricultural practices [6], animal feeding setups [7,8], dairy/poultry industries [9,10], composting facilities [11,12], fishmeal plants [13], gasoline vehicles [14], and from specific chemical industries [15]. Considering the respective toxicity and health concerns, various technologies have been employed for the removal of gaseous ammonia including bio-filters $[3,13,16,17]$, catalytic systems [18] biological treatment [11], scrubbers [5] and other specific technologies such as nano-particles applications [4].

Adsorption and activated carbon based technologies have also been widely used for several environmental applications [19-24]. To that end, the conversion of agricultural wastes into granular activated carbon (GAC) and its use for pollution control applications, has also attracted much attention, considering its multi-faceted and inherent economical, and environmental advantages. Considering this, activated carbon from different carbon-rich sources including wood [1], palm shell [25], and coal and coconut shell [26] has been used for gaseous ammonia treatment. Several studies also report gaseous ammonia treatment using modified activated carbon. The respective modification methods include oxidation [27], acids [28], inorganic-agents [29], ozone [30], $\mathrm{ZnCl}_{2}, \mathrm{HNO}_{3}$ and $\left(\mathrm{NH}_{4}\right)_{2} \mathrm{~S}_{2} \mathrm{O}_{8}$ [26], and aluminum-zirconium poly-cations [15]. 
It is also important to note that extensive date fruit farming in the Middle East, North Africa, Sothern Europe, Americas (including California, Texas, Arizona, Mexico), and the Subcontinent region, produces huge agricultural wastes from the date palm trees [31]. Several studies also report green and environmental applications of date pits [32-35]. Furthermore, Jibril et al. [36] also studied production of activated carbon using date tree stem. The authors employed both acid and base activation methods. For phosphoric acid activation method, $S S A_{\mathrm{BET}}$ values reported are within 632 and $1100 \mathrm{~m}^{2} / \mathrm{g}$. The highest $S S A_{\mathrm{BET}}$ value was noted at $500^{\circ} \mathrm{C}$ activation temperature. For the base activation procedure (using potassium hydroxide) the $S S A_{\mathrm{BET}}$ values were within 278 and $947 \mathrm{~m}^{2} / \mathrm{g}$, with the highest $S S A_{\mathrm{BET}}$ noted at $600{ }^{\circ} \mathrm{C}$. On the other hand, Alhamed [37] reports production of activated carbon from date pits using zinc chloride chemical activation. The respective activated carbon produced at $700{ }^{\circ} \mathrm{C}$ showed $S S A_{\mathrm{BET}}$ value of $951 \mathrm{~m}^{2} / \mathrm{g}$. Also, Al-Muhtaseb et al. [38] report production of activated carbon from date pits with $S S A_{\mathrm{BET}}$ value of $690 \mathrm{~m}^{2} / \mathrm{g}$ using physical activation at $900{ }^{\circ} \mathrm{C}$. Belhachemi et al. [39] also employed date pits with physical activation for the production of activated carbon at $800{ }^{\circ} \mathrm{C}$. The authors prepared several activated carbon samples under a varying set of conditions and report $S S A_{\mathrm{BET}}$ values between 652 and $1669 \mathrm{~m}^{2} / \mathrm{g}$. Bouchelta et al. [40] also report production of activated carbon from date pits with $S S A_{\mathrm{BET}}$ value up to $635 \mathrm{~m}^{2} / \mathrm{g}$ using physical activation. Daifullah and Girgis [41] report production of activated carbon from date pits using chemical activation. The respective activated carbon showed $S S A_{\mathrm{BET}}$ value of $771 \mathrm{~m}^{2} / \mathrm{g}$. El-Naas et al. [42] also report production of activated carbon from date pits using carbon dioxide at $900{ }^{\circ} \mathrm{C}$ with $S S A_{\mathrm{BET}}$ value $490 \mathrm{~m}^{2} / \mathrm{g}$. Girgis and El-Hendawy [43] also report production of activated carbon from date pits using phosphoric acid based activation under a varying set of conditions. Results showed $S S A_{\text {BET }}$ values up to $945 \mathrm{~m}^{2} / \mathrm{g}$ at $700{ }^{\circ} \mathrm{C}$. Hameed et al. [44] also report production of activated carbon from date pits employing potassium hydroxide and report $S S A_{\text {BET }}$ value $763 \mathrm{~m}^{2} / \mathrm{g}$ at $850{ }^{\circ} \mathrm{C}$. Merzougui and Addoun [45] also report production of activated carbon from date pits using chemical activation under a varying conditions and indicate $S S A_{\mathrm{BET}}$ values up to $1040 \mathrm{~m}^{2} / \mathrm{g}$.

The above given literature review shows the production of GAC from date pits, which has also been successfully used for several water treatment applications. Furthermore, the aforementioned literature review also indicated the importance of toxic gaseous ammonia removal from the respective contaminated streams. However, the application of date palm pits based GAC for the treatment of gaseous ammonia pollution control, has not been explored. Nevertheless, environmental regulations do require appropriate treatment of toxic gaseous emissions including ammonia $\left(\mathrm{NH}_{3}\right)$ considering the respective health concerns. The present work therefore focuses on gaseous ammonia treatment using GAC derived from date palm pits. Effect of process variables including the influent gas flow rate, gas concentration, and GAC column length (bed depth) on to ammonia gas adsorption was investigated. Results as reported in this communication show that DPP based GAC can successfully treat gaseous ammonia under a varying set of process conditions.

\section{Materials and Methods}

\subsection{Materials}

Some specific chemicals and materials that were used in the present work included the following: $\mathrm{pH}$ calibration standards (FISHER), phosphoric acid $\left(\mathrm{KH}_{2} \mathrm{PO}_{4} 85 \% w / w\right.$; BAKER), Liquid Nitrogen (at $77 \mathrm{~K})$, and ammonia standard gas $(100 \mathrm{ppmv})$. The high purity air was generated using a zero air setup (Thermo Scientific, Model 111, Waltham, MA, USA). A commercial GAC sample, i.e., Filtrasorb 400 (Calgon, Moon Township, PA, USA), was also employed for gaseous ammonia adsorption and the outcomes were compared with the respective date pits based GAC results to realize latter's efficiency. 


\subsection{Granular Activated Carbon (GAC) Production}

Initially the date palm pits were acquired from a local source, and were then reduced to size of 1-1.2 mm using a professional cutter. The respective date pits particles were then converted into GAC using a chemical activation process [46]. For the initial impregnation step, the date pits particles were first dried in an oven at $100{ }^{\circ} \mathrm{C}$. The respective date particles and phosphoric acid $(60 \% w / w)$ were mixed at impregnation ratio of $1.6 \mathrm{~mL} / \mathrm{g}$ (acid/date-pits). This mixture was left overnight for soaking. Then the respective mixture was shifted to $25 \mathrm{~mm} \times 300 \mathrm{~mm}$ (diameter $\times$ length) stainless steel tubes, which had exit holes at both ends (to allow the produced gases and vapors to exit). These stainless steel setup was later on shifted to a professional furnace (Lenton, Hope Valley, UK). After this, the furnace temperature was raised to $500^{\circ} \mathrm{C}$, at a gradual increase rate of $10^{\circ} \mathrm{C}$ per minute. The respective tubes holding the acid/date-pits mixture, remained in the furnace for $2 \mathrm{~h}$. After this step, the furnace temperature was gradually cooled to the room temperature, after which the tubes were transferred to a standard desiccator. The end product as retrieved from the tubes was continuously washed using high purity water (CORNING Mega Pure ${ }^{\mathrm{TM}}$ System). This process of washing continued till the washing water $\mathrm{pH}$ reached to near neutral. The resulting product was dried at $110{ }^{\circ} \mathrm{C}$ using a standard oven (Fisher Scientific, Hampton, NH, USA), and then appropriately sieved to obtain around $1 \mathrm{~mm}$ particles employing U.S. sieve size \# 18.

\subsection{Gaseous Ammonia Dynamic Adsorption Studies}

The dynamic adsorption studies were completed using a bench scale experimental setup [47]. Figure 1a provides the layout of respective setup that was used for the gaseous ammonia dynamic adsorption experiments. It consisted of following major individual components: Ammonia gas standard cylinder, high purity air supply unit, standard flow meters connecting the gas sources to the activated carbon column via a series of valves to control gas flow and gas concentration, GAC column, and ammonia gas analyzer. The column containing the produced GAC (through which gaseous ammonia was passed continuously) was made of Fluorinated Ethylene Propylene (FEP) tubing with an inner diameter of $6.35 \mathrm{~mm}$ and outer diameter of $7.938 \mathrm{~mm}$. The column was first provided with an inert support at the bottom followed by GAC filling that was then topped with the same inert material. The specific and separate gas flows from the high purity air supply source (Thermo Scientific, Model 111, Waltham, MA, USA) and the standard ammonia gas cylinder were obtained using separate/dedicated standard flow controllers (Cole Palmer, Vernon Hills, IL, USA). After this, the continuous streams from the high purity air source and ammonia gas standard were mixed (at specific flow rates) to realize the desired influent gaseous ammonia concentration (for the adsorption experiment). The respective gaseous ammonia stream was then continuously passed in a down flow direction through the above mentioned GAC column. The effluent/exiting gas (after treatment) was then tested as described in Section 2.4. The gaseous ammonia removal experiments were conducted at different process conditions including varying flow rates and ammonia concentrations. The obtained responses included the Breakthrough Time (run time at which $5 \%$ of influent ammonia is exiting the column) and Exhaustion Time (run time at which $95 \%$ of influent ammonia is exiting the column). To obtain these responses, the effluent ammonia results were plotted against time for the whole test duration. 


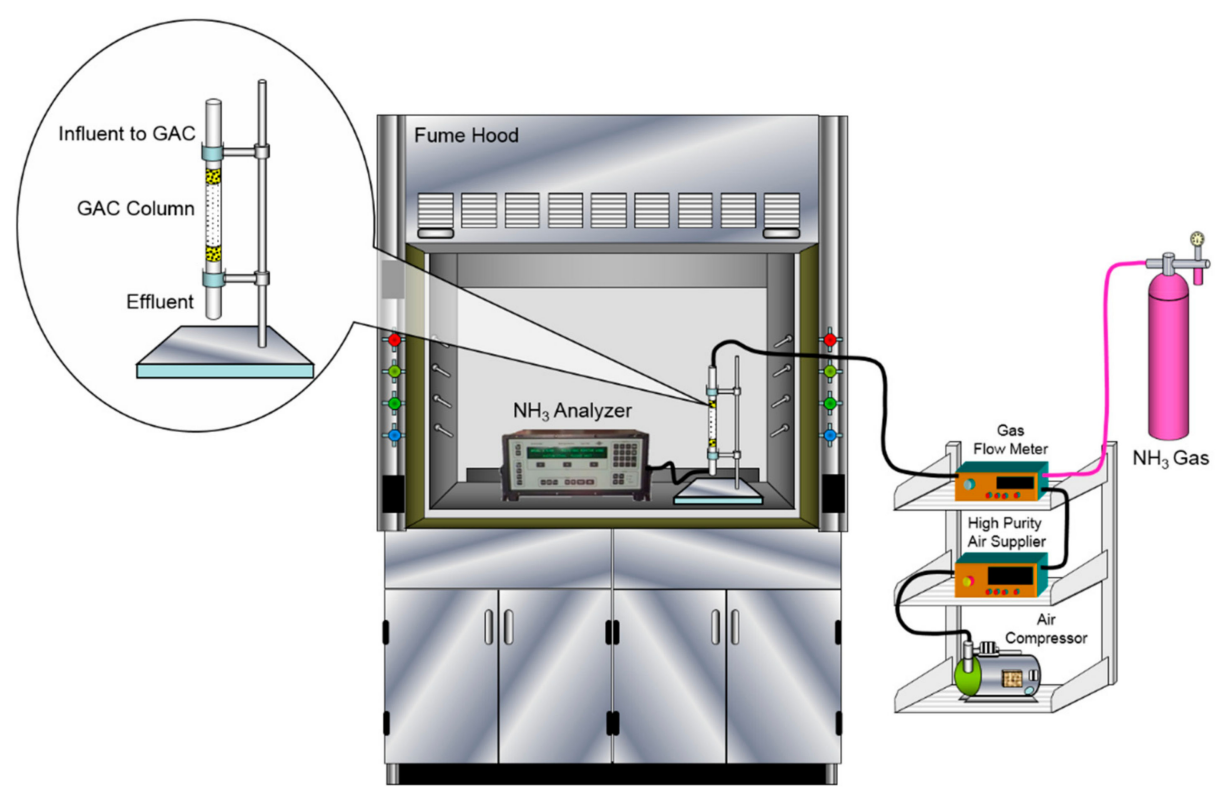

(a)

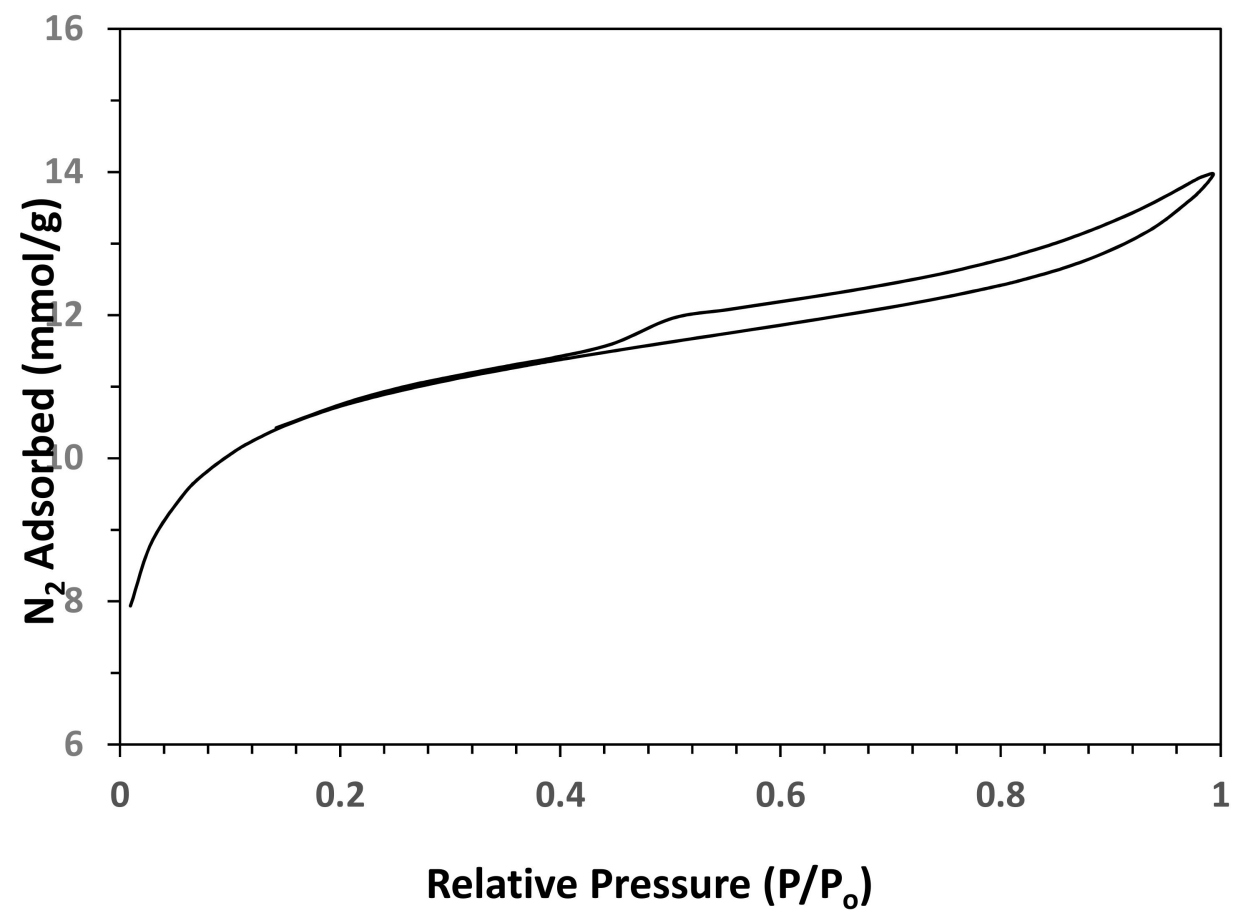

(b)

Figure 1. Cont. 


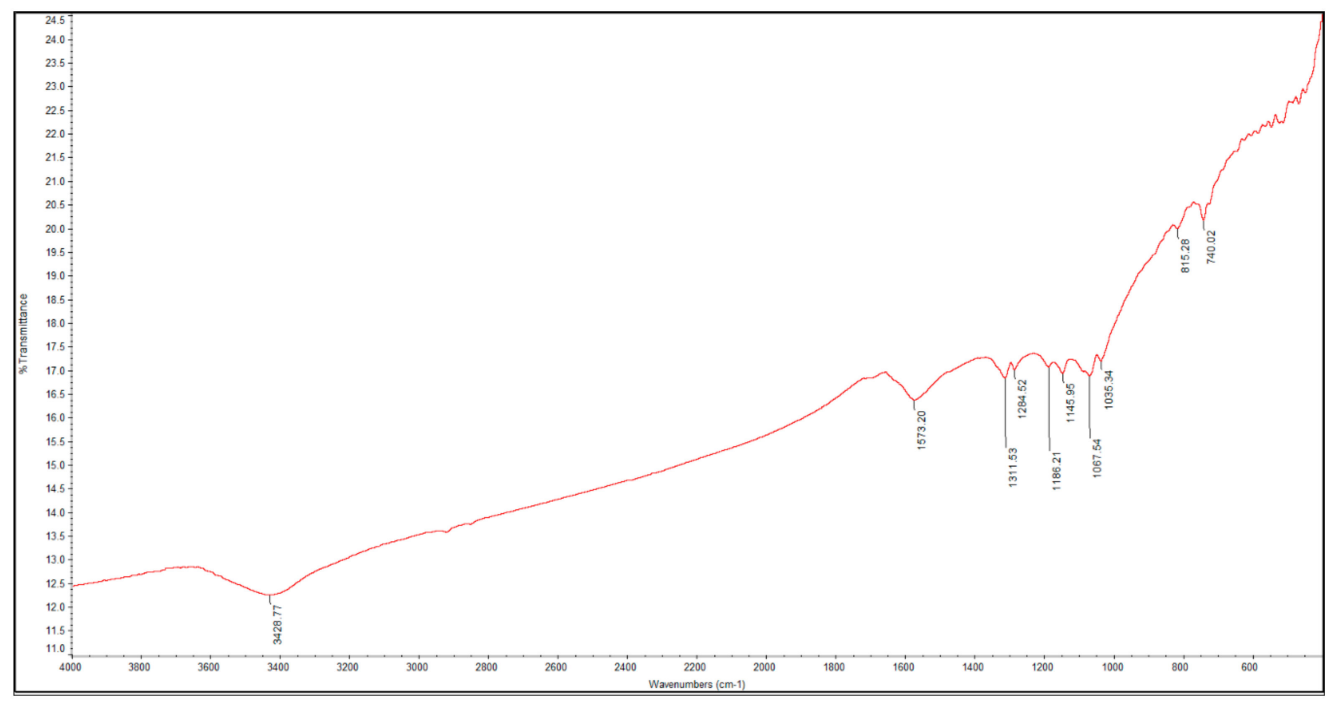

(c)

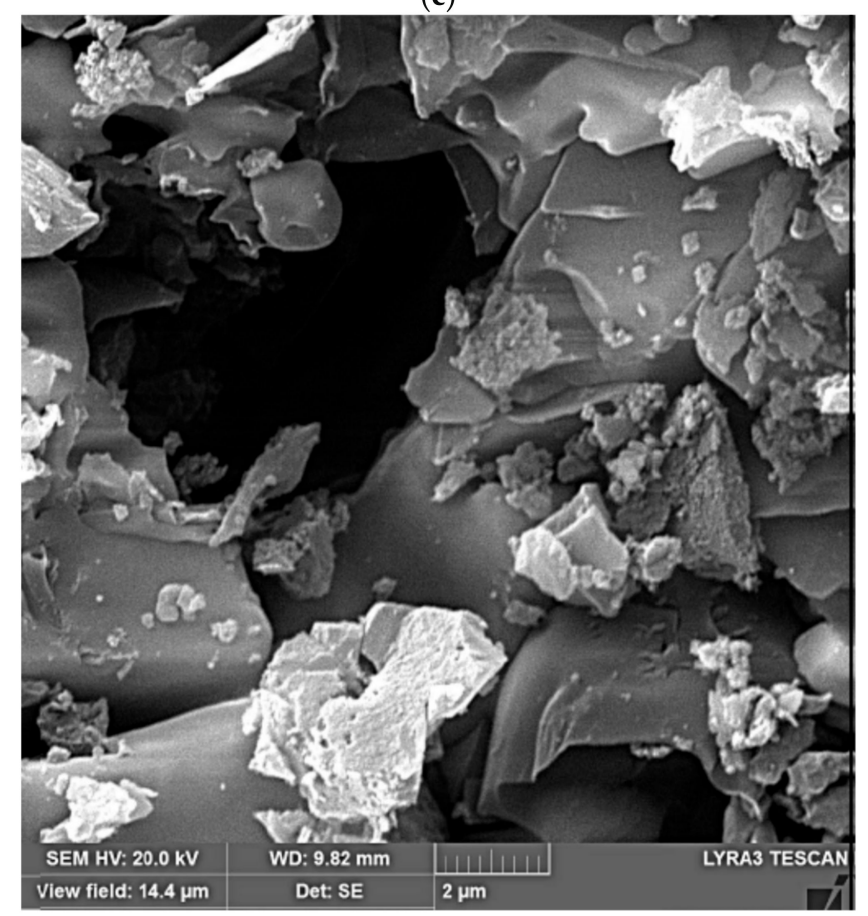

(d)

Figure 1. (a) The experimental setup used for the dynamic continuous ammonia gas flow adsorption experiments. (b) The BET adsorption isotherm findings for the date pits granular activated carbon (GAC) (Preparation conditions: Phosphoric acid (60\% w/w); Impregnation ratio $1.6 \mathrm{~mL} / \mathrm{g}$ (acid/date-pits); Furnace temperature $500{ }^{\circ} \mathrm{C}$ for $2 \mathrm{~h}$ ). (c) The transmittance vs wavenumber Fourier Transform Infrared Spectroscopy (FTIR) findings for the produced GAC (Preparation conditions: Phosphoric acid (60\% $w / w)$; Impregnation ratio $1.6 \mathrm{~mL} / \mathrm{g}$ (acid/date-pits); Furnace temperature $500{ }^{\circ} \mathrm{C}$ for $2 \mathrm{~h}$ ). (d) SEM findings for the GAC produced from date palm pits (Preparation conditions: Phosphoric acid (60\% w/w); Impregnation ratio $1.6 \mathrm{~mL} / \mathrm{g}$ (acid/date-pits); Furnace temperature $500{ }^{\circ} \mathrm{C}$ for $2 \mathrm{~h}$ ).

\subsection{Analytical Methods}

The specific surface area $\left(S S A_{B E T}\right)$ of the produced activated carbon was determined employing a state-of-the-art physio-sorption setup (ASAP 2020, Micromeritics, Norcross, GA, USA). The conventional nitrogen adsorption equilibrium data as given in Figure $1 \mathrm{~b}$ was eventually employed for the respective analysis. The specific surface area $\left(S S A_{B E T}\right)$ value of produced GAC was determined to be $822 \mathrm{~m}^{2} / \mathrm{g}$. The respective average pore width was determined to be $23.01 \AA((4 \mathrm{~V} / \mathrm{A})$ by BET)). 
The results indicated most specific surface area, i.e., $735 \mathrm{~m}^{2} / \mathrm{g}$ to be in the porous region of produced GAC. The total carbon content $(w / w)$ of respective activated carbon was determined to be around $82 \%$ (AnalytikJena Multi EX 2000, Jena, Germany). The Fourier Transform Infrared Spectroscopy (FTIR) characterization of the produced date pits based GAC was also completed employing the Fourier transform infrared technique (FTIR, Thermo Scientific, Waltham, MA, USA). The respective findings are given in Figure 1c. The salient functional groups, as noted from the respective FTIR characterization, at the GAC surface, included $\mathrm{O}-\mathrm{H}, \mathrm{C}-\mathrm{H}, \mathrm{C}-\mathrm{O}$, and $\mathrm{S}=\mathrm{O}$. The respective surface functional groups are expected to initiate ammonia uptake by the activated carbon. Furthermore, hydrophobic interactions and hydrogen bonding transpiring between the ammonia molecules and surface oxygen based functional groups can also initiate and enhance gaseous ammonia adsorption on activated carbon surface [22]. These results are invoked later to explain the ammonia adsorption results. The effluent/exiting gas (after treatment) from dynamic continuous gas flow experiments was tested using a state-of-the-art gaseous ammonia analyzer (Model 17i, Thermo Scientific, Waltham, MA, USA). Furthermore, Figure $1 \mathrm{~d}$ provides the SEM results for the date pits based GAC. The respective results indicate a porous structure that eventually helps to adsorb the target pollutants that is similar to as noted in previous studies for activated carbon [48].

\section{Results and Discussion}

\subsection{Effect of Ammonia Gas Concentration}

Initially, a set of experiments were conducted to assess the effect of influent ammonia concentration on to its adsorption based removal. To that end, several experiments were conducted at varying influent gaseous ammonia concentrations, using GAC column lengths of 6 and $8 \mathrm{~cm}$. The initial experiments were conducted between 2.5 and $7.5 \mathrm{ppmv}$ gaseous ammonia for the $8 \mathrm{~cm}$ GAC column. The respective findings are shown in Figure 2a,b, at gas flow rates of 1.1 and $2.2 \mathrm{~L} / \mathrm{min}$, respectively. It is evident that with a gradual decrease in the influent ammonia concentration, the breakthrough point also shifts towards longer times. For example, the results in Figure 2a show the following breakthrough trend: $1295 \mathrm{~min}(2.5 \mathrm{ppmv})>712 \mathrm{~min}(5 \mathrm{ppmv})>532 \mathrm{~min}(7.5 \mathrm{ppmv})$. Furthermore, the exhaustion time values for the respective experiments also show higher run times at lower gaseous ammonia concentrations, i.e., $4000 \mathrm{~min}(2.5 \mathrm{ppmv})>2312 \mathrm{~min}(5 \mathrm{ppmv})>1574 \mathrm{~min}(7.5 \mathrm{ppmv})$. Furthermore, the adsorption trends in Figure 2 typically show a broader adsorption breakthrough curve that indicates comparatively larger length of the mass transfer zone (MTZ). This is somewhat different from the adsorption of benzene onto DPP based GAC that showed a sharp breakthrough curve [24]. Such a different trend in case of ammonia may be ascribed to basic nature of ammonia moieties that can interact with the surface acidic groups [29]. An increase in the incoming gaseous ammonia and its transfer from the bulk gas phase to the surface of GAC, will initiate a faster consumption of GAC surface adsorption sites (including those in the pores). As the respective surface adsorption sites are fixed and limited, it is expected that an earlier breakthrough and also an earlier exhaustion, will transpire at higher influent ammonia concentrations. Furthermore, additional experiments conducted under similar conditions but at $2.2 \mathrm{~L} / \mathrm{min}$, also show qualitatively similar trends (Figure $2 \mathrm{~b}$ ). The effect of varying influent gaseous ammonia concentration on to breakthrough/exhaustion was further investigated using a $6 \mathrm{~cm}$ GAC column at 3 and $10 \mathrm{ppmv}$ ammonia. The respective findings are given in Figure 3. Similar to Figure 2 findings, an increase in the gas concentration from 3 to $10 \mathrm{ppmv}$, reduces the breakthrough time from 595 and $159 \mathrm{~min}$, and the exhaustion time from 1231 to $354 \mathrm{~min}$. 


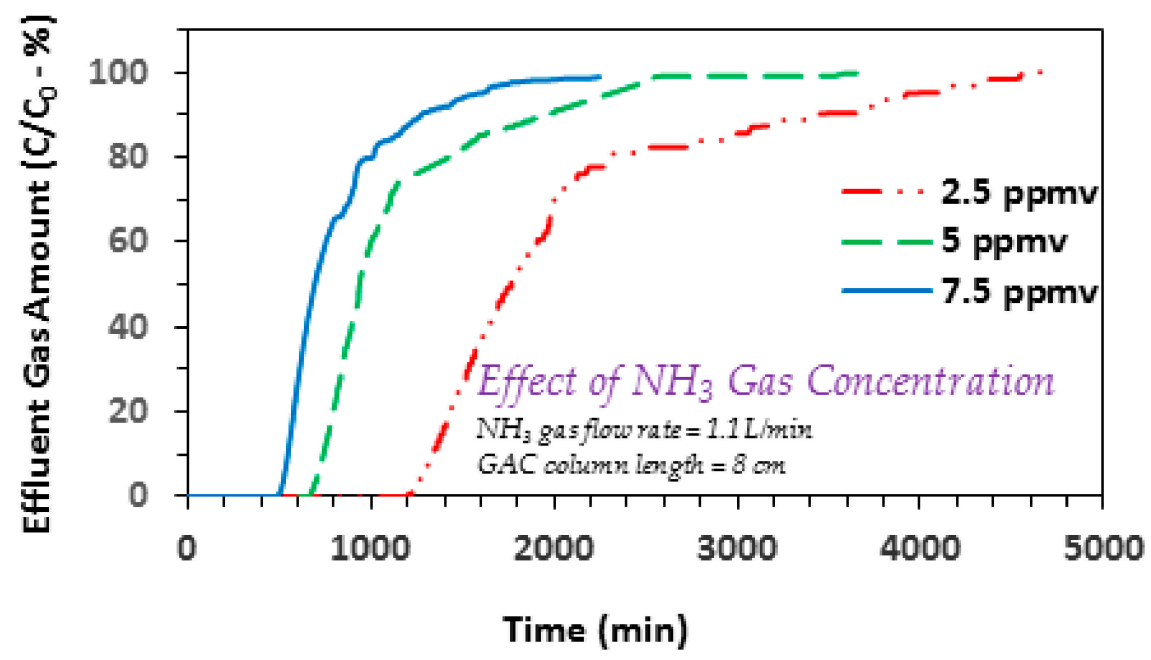

(a)

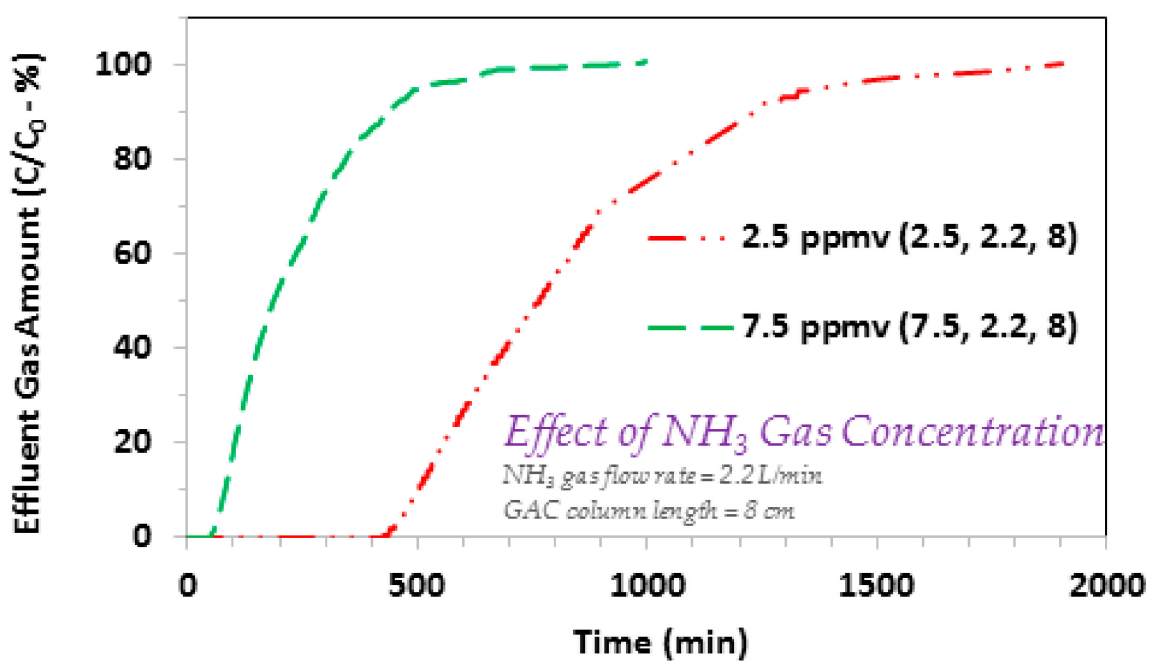

(b)

Figure 2. (a) Effect of influent ammonia gas concentration on the adsorption breakthrough curve profile of ammonia gas on to GAC produced from date palm pits. (a) GAC $S S A_{B E T}=822 \mathrm{~m}^{2} / \mathrm{g}$ and average pore width $=23.01 \AA$; ammonia/ $/ \mathrm{NH}_{3}$ gas flow rate $=1.1 \mathrm{~L} / \mathrm{min}$; influent ammonia $/ \mathrm{NH}_{3}$ gas concentrations $2.5,5$, and 7.5 ppmv; GAC column length $=8 \mathrm{~cm}$; GAC bed dia. $6.35 \mathrm{~mm}$. (b) GAC $S S A_{B E T}=822 \mathrm{~m}^{2} / \mathrm{g}$ and average pore width $=23.01 \AA$; ammonia/ $/ \mathrm{NH}_{3}$ gas flow rate $=2.2 \mathrm{~L} / \mathrm{min}$; influent ammonia $/ \mathrm{NH}_{3}$ gas concentrations 2.5, and 7.5 ppmv; GAC column length $=8 \mathrm{~cm}$; GAC bed dia. $6.35 \mathrm{~mm}$.

Further comparing the results for 2.5 and 5 ppmv systems from Figure $2 \mathrm{a}$, the decrease in breakthrough and exhaustion time values is approximately proportional to the respective increase in ammonia concentration. This shows that differences between the mass of ammonia transferred from the bulk gas phase to the GAC surface at both flow rates, is minimal. This suggests that the bulk diffusion and pore diffusion of gaseous ammonia is sufficiently high and therefor the overall mass transfer is not significantly affected by the respective increase in bulk ammonia gas concentration. A similar trend is also noted comparing the respective breakthrough time values (595 and $159 \mathrm{~min}$ ) and the exhaustion time values (1231 and $354 \mathrm{~min}$ ), for the 3 and 10 ppmv ammonia systems using $6 \mathrm{~cm}$ GAC column (Figure 3). Considering the importance of this point, especially from practical applications point of view, one additional experiment was conducted at $2.5 \mathrm{ppmv}$ and the breakthrough and exhaustion time values were noted to be 747 and $1476 \mathrm{~min}$, respectively (Figure 3). Comparing these results with the $10 \mathrm{ppmv}$ findings (Figure 3) that showed breakthrough and exhaustion time values of 159 and $354 \mathrm{~min}$, respectively, an increase in influent ammonia gas concentration to four 
times causes an approximately similar decrease in both the breakthrough and exhaustion times. This observation was further explored by investigating the effect of varying gaseous ammonia flow rates and GAC column lengths, on the respective breakthrough/exhaustion time trends, with details provided in the sections given below.

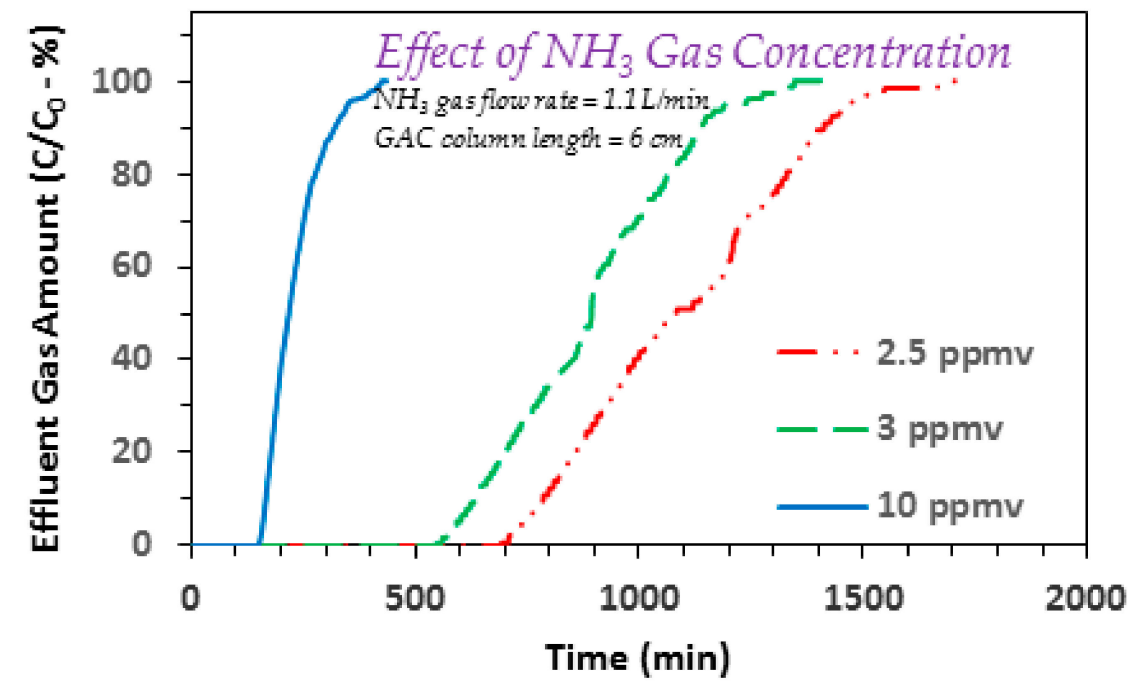

Figure 3. Effect of influent ammonia gas concentration on the adsorption breakthrough curve profile of ammonia gas on to GAC produced from date palm pits (GAC SSA $B E T=822 \mathrm{~m}^{2} / \mathrm{g}$ and average pore width $=23.01 \AA$; ammonia $/ \mathrm{NH}_{3}$ gas flow rate $=1.1 \mathrm{~L} / \mathrm{min}$; influent ammonia $/ \mathrm{NH}_{3}$ gas concentrations $2.5,3$, and 10 ppmv; GAC column length $=6 \mathrm{~cm}$; GAC bed dia. $6.35 \mathrm{~mm}$ ).

\subsection{Effect of Ammonia Gas Flow Rate}

The present study also investigated the effect of gas flow rate on to ammonia adsorption using the date pits based GAC. Figure 4 provides the respective results for gas flow rates between 1.1 to $3.3 \mathrm{~L} / \mathrm{min}$ (at an influent gaseous ammonia concentration of $5 \mathrm{ppmv}$ and GAC column length of $8 \mathrm{~cm}$ ). Typically, a gradual increase in the ammonia gas flow rate also results in a gradual decrease in the respective breakthrough time and exhaustion time responses (Figure 4). For example, the breakthrough times at flow rates of 1.1, 1.65, 2.2, and $3.3 \mathrm{~L} / \mathrm{min}$ are noted to be $712,383,272$, and $197 \mathrm{~min}$, respectively (Figure 4). Hence higher breakthrough time values transpire at lower ammonia gas flow rates. Furthermore, exhaustion times of 2312, 1673, 1315, and 1213 min are also noted for $1.1,1.65,2.2$, and $3.3 \mathrm{~L} / \mathrm{min}$ flow rate studies, respectively. This is similar to the aforementioned breakthrough time trend that can be explained as follows. The mass transfer rate of ammonia molecules from gas phase to GAC surface is also comparatively small at lower influent gas flow rates. Hence the GAC surface sites being occupied per unit time is also lesser, yielding higher breakthrough time and exhaustion time responses as compared to those at higher gas flow rates (Figure 4). These findings are important especially for practical applications. To build on these important results, the effect of GAC column length on gaseous ammonia removal was also studied, as given below.

\subsection{Effect of GAC Column Length}

Another set of experiments conducted at varying GAC column lengths (and $1.1 \mathrm{~L} / \mathrm{min}$ and 5 ppmv gas flow rate and concentration, respectively) indicated higher breakthrough and exhaustion time values for larger GAC column depths (Figure 5). The 4,6, and $8 \mathrm{~cm}$ GAC column lengths show breakthrough at 197, 385, and $712 \mathrm{~min}$, respectively, whereas the respective exhaustion time values are 1054, 1134, and $2312 \mathrm{~min}$. Both trends show an increase as the GAC column length increases from 4 to $8 \mathrm{~cm}$. To further assess this subject, another experiment was conducted using the shortest $(4 \mathrm{~cm})$ GAC column at three times higher flow rate of $3.3 \mathrm{~L} / \mathrm{min}$ (and $5 \mathrm{ppmv}$ ). This caused a reduction in 
the breakthrough time from $197 \mathrm{~min}$ (for $1.1 \mathrm{~L} / \mathrm{min}$ ) to $51 \mathrm{~min}$ (for $3.3 \mathrm{~L} / \mathrm{min}$ ). An earlier study also indicated higher gaseous ammonia adsorption with an increase in the initial (zinc chloride impregnated) activated carbon sample [49]. However, above an optimum zinc chloride amount, the adsorption capacity actually decreased. The authors ascribed such a decrease in gaseous ammonia adsorption to the agglomeration of zinc chloride moieties on to activated carbon surface. Furthermore, and as also stated earlier that the adsorption trends in Figures 2-5, typically show a broader adsorption breakthrough curve that indicates comparatively larger length of the mass transfer zone (MTZ). This is different from the adsorption of benzene onto DPP based GAC that showed a sharp breakthrough curve [24]. Such a different trend in case of ammonia may be ascribed to the basic nature of ammonia moieties that can interact with the surface acidic groups [29]. Furthermore, the adsorbed ammonia can also dissolve in moisture within the pore space, thus resulting into its accumulation and buildup. This will cause formation of cationic ammonium species that could possibly interact with the surface of activated carbon via surface functional groups, acid-base reactions, and also through van der Waals interactions, which are simplified as given below [29].

$$
\begin{gathered}
\underline{\mathbf{N H}}_{3} \text { (gas) } \leftrightarrow \underline{\mathbf{N H}}_{3} \text { (aqueous) } \\
\underline{\mathbf{N H}}_{3} \text { (aqueous) }+\mathrm{H}^{+} \leftrightarrow \mathbf{\mathbf { N H }}_{4}^{+} \text {(aqueous) } \\
\text { GAC-O }^{-}+\underline{\mathbf{N H}}_{4}^{+} \leftrightarrow \text { GAC-O-NH}_{4}
\end{gathered}
$$

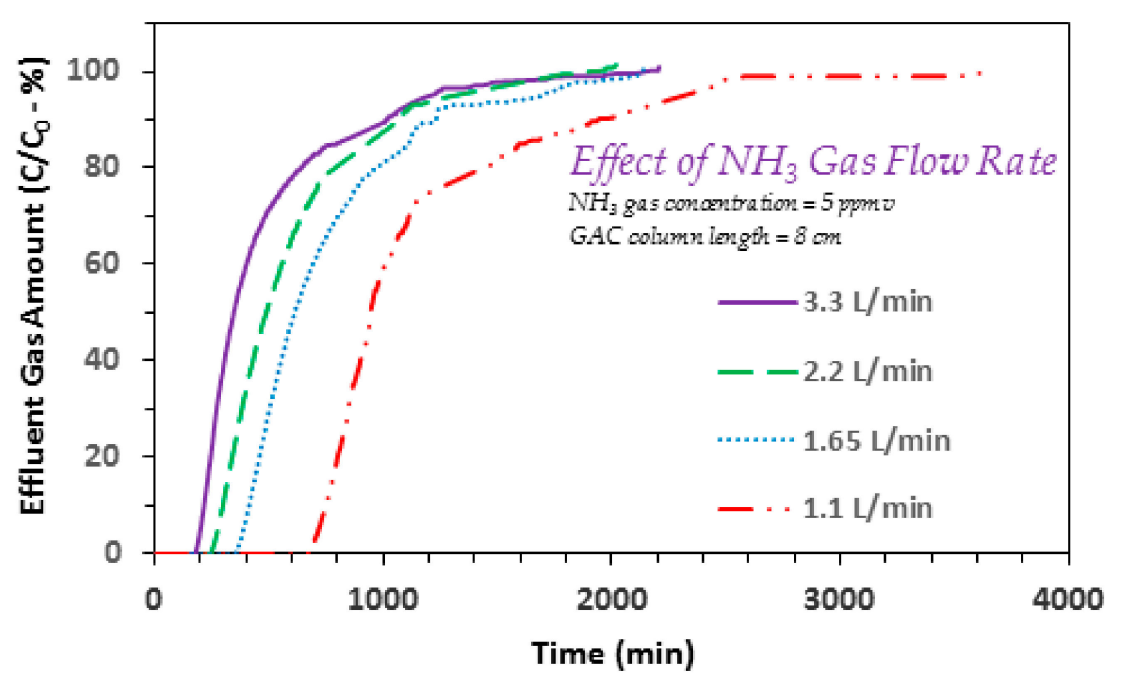

Figure 4. Effect of influent ammonia/ $\mathrm{NH}_{3}$ gas flow rate on the adsorption breakthrough curve profile of ammonia gas on to GAC produced from date palm pits (GAC SSA $A_{B E T}=822 \mathrm{~m}^{2} / \mathrm{g}$ and average pore width = 23.01 $\AA$; ammonia/ $/ \mathrm{NH}_{3}$ gas flow rates = 1.1, 1.65, 2.2, and $3.3 \mathrm{~L} / \mathrm{min}$; influent ammonia/ $\mathrm{NH}_{3}$ gas concentrations 5 ppmv; GAC column length $=8 \mathrm{~cm}$; GAC bed dia. $6.35 \mathrm{~mm}$ ).

These mechanisms could also possibly explain the broader ammonia adsorption curves a noted in Figures 2-5. Furthermore, to check out the data reproducibility, two experiments for 5 ppmv ammonia gas concentration, at $1.1 \mathrm{~L} / \mathrm{min}$ gas flow rate and GAC column length of $4 \mathrm{~cm}$, yielded breakthrough time values of 197 and $227 \mathrm{~min}$. Similarly, another set of experiments completed at 5 ppmv ammonia gas concentration, $1.1 \mathrm{~L} / \mathrm{min}$ gas flow rate and GAC column length of $8 \mathrm{~cm}$, yielded breakthrough time values of 712 and $750 \mathrm{~min}$. These values are close, especially for the bench scale dynamic flow studies. It should also be noted that real life applications require the GAC column length to be larger than the critical GAC bed depth, i.e., column length just enough to avoid breakthrough at time zero. These observations suggest a longer GAC column length for gaseous ammonia adsorption. These findings show that with a careful selection of respective operational design parameters, the date palm pits based GAC can be successfully used for gaseous ammonia treatment. To build on these 
encouraging results, a commercial GAC was also used for comparison purpose, and the respective findings are given below.

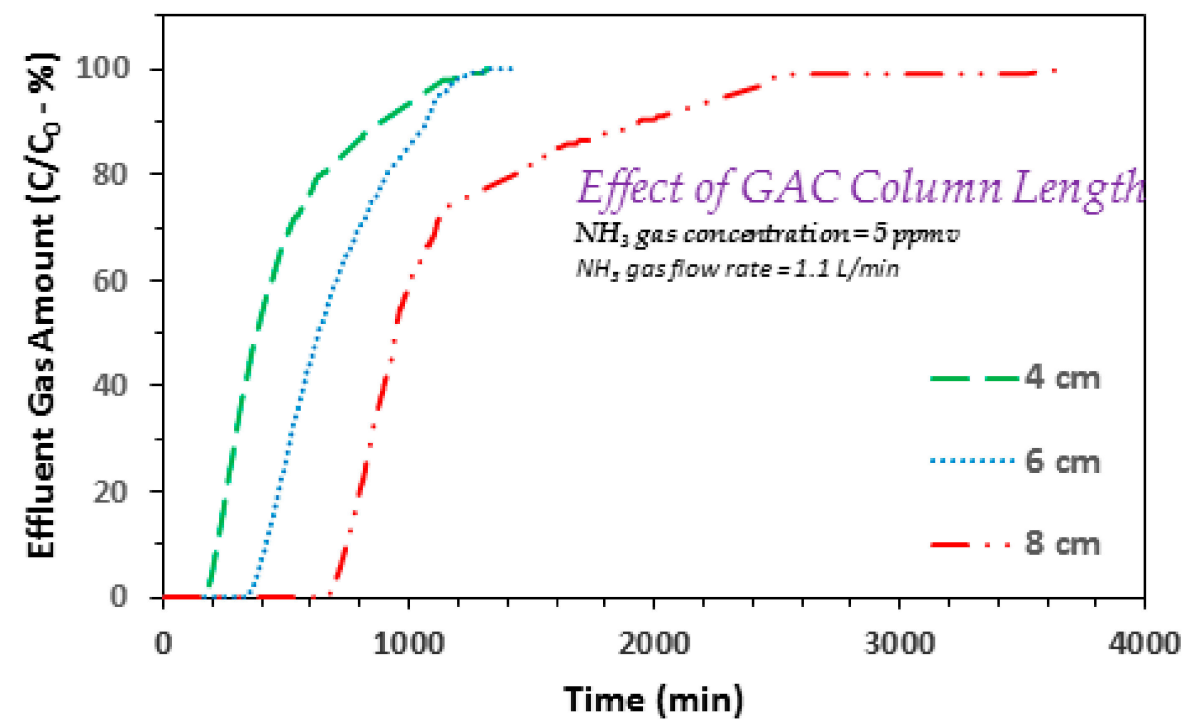

Figure 5. Effect of GAC column length on the adsorption breakthrough curve profile of ammonia gas on to GAC produced from date palm pits (GAC SSABET $=822 \mathrm{~m}^{2} / \mathrm{g}$ and average pore width $=$ $23.01 \AA$; ammonia $/ \mathrm{NH}_{3}$ gas flow rate $=1.1 \mathrm{~L} / \mathrm{min}$; influent ammonia/ $\mathrm{NH}_{3}$ gas concentrations 5 ppmv; $\mathrm{GAC}$ column lengths $=4,6$, and $8 \mathrm{~cm}$; GAC bed dia. $6.35 \mathrm{~mm}$ ).

\subsection{Comparison with a Commercial GAC}

The efficiency of GAC produced from date palm pits was also compared with a commercial GAC, i.e., Filtrasorb 400 (Calgon, Moon Township, PA, USA). The respective findings (at ammonia gas flow rate $2.2 \mathrm{~L} / \mathrm{min}$; influent ammonia gas concentration 5 ppmv; GAC column length $6 \mathrm{~cm}$ ) as given in Figure 6, show higher breakthrough and exhaustion capacity for the date palm pits based GAC. The average pore width of the produced GAC, which is $\sim 23 \AA$, is much wider than $3.26 \AA$ molecular-size of ammonia $[2,50]$. This makes it very conducive for the ammonia molecules to diffuse through the pores into the pore-volume of produced GAC, which also holds majority of specific surface area, i.e., $735 \mathrm{~m}^{2} / \mathrm{g}$. Furthermore, the aforementioned discussion on higher bulk and pore diffusion of gaseous ammonia, yielding larger gaseous ammonia mass transfer from the bulk gas phase to the produced GAC surface at higher ammonia concentrations (Figures 2 and 3), can also explain the noted better gaseous ammonia efficiency of produced GAC as compared to the commercial GAC (Figure 6). It has also been reported that gaseous ammonia moieties can initiate hydrogen bonding with the acidic functional groups at the GAC surface (in an acid-base interaction), with higher adsorption noted for the activated carbons with larger surface acidic groups [30,51,52]. In one study, which observed reduced specific surface area of GAC with ozone treatment, still an increased introduction of surface acidic groups (because of ozone treatment) yielded higher ammonia removal efficiency [30]. In another study, an increased gaseous ammonia uptake for activated carbon modified with different acids was also noted to be proportional to the introduction of acidic surface functional groups [28], and also oxygen surface functional groups $[25,26]$. In the present investigation, employing the FTIR findings indicated some salient functional groups at the produced GAC surface including $\mathrm{O}-\mathrm{H}, \mathrm{C}-\mathrm{H}, \mathrm{C}-\mathrm{O}$, and $\mathrm{S}=\mathrm{O}$ groups. It is also interesting to note that the gaseous ammonia species because of its molecular structure and electrons distribution, can serve both as a hydrogen-bond donor and acceptor [51]. Hence the gaseous ammonia molecule is in a unique position to bond with the above mentioned functional groups at the produced GAC surface. Wu et al. [22] who studied adsorption of N-based atrazine pollutant onto several activated carbon samples, both in the absence and presence of Bisphenol A, discuss several possible atrazine uptake mechanisms. It was noted that factors including activated 
carbon's polarity, specific surface area, and porosity, did affect atrazine adsorption on to activated carbon. Also hydrophobic interactions, hydrogen bonding, and $\pi-\pi$ exchanges, were considered to initiate adsorption. For example, hydrogen bonding between the N-H moieties and surface carbonyl groups, was indicated to cause atrazine uptake by the activated carbon surface. Similarly, hydrophobic interactions and hydrogen bonding transpiring between the ammonia molecules and surface oxygen based functional groups, can also initiate and enhance gaseous ammonia adsorption on to activated carbon surface. Additionally, other forces including the van der Waals interactions, can also contribute towards ammonia adsorption. In summary, the findings reported in the present work are promising, paving the path for practical applications of date palm pits based GAC for gaseous ammonia treatment.

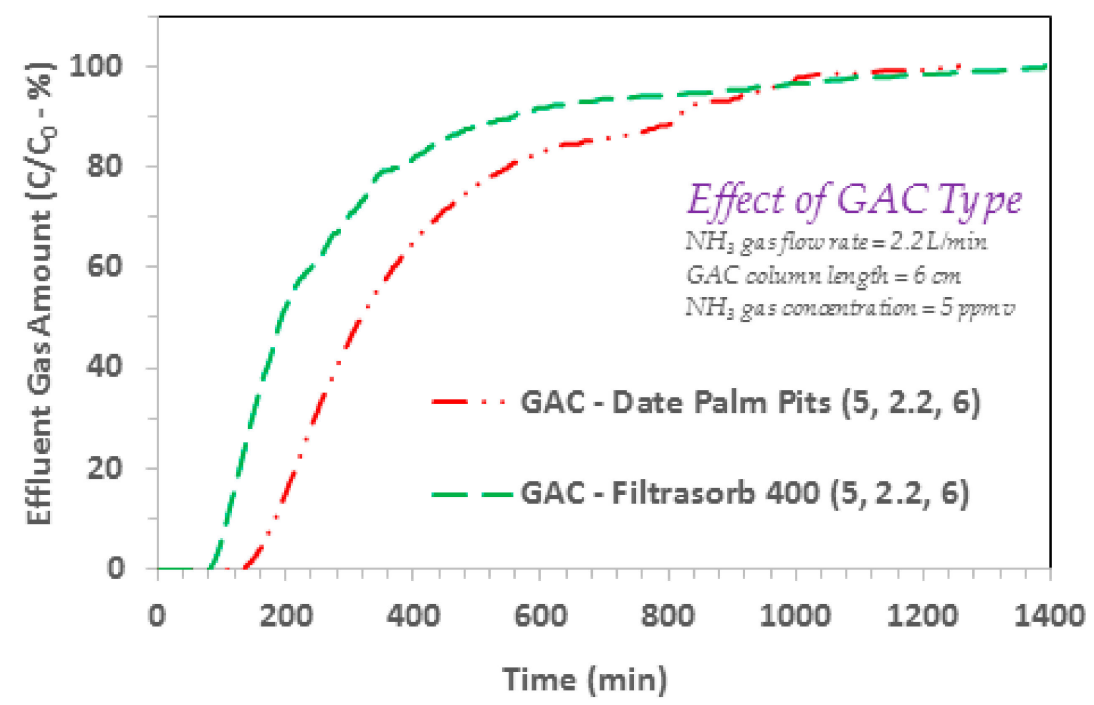

Figure 6. Effect of GAC type on the adsorption breakthrough curve profile of ammonia gas on to GAC produced from date palm pits $\left(S S A_{B E T} 822 \mathrm{~m}^{2} / \mathrm{g}\right.$ for date palm pits based GAC and $1100 \mathrm{~m}^{2} / \mathrm{g}$ for Filtrasorb $400 \mathrm{GAC}$; ammonia/ $\mathrm{NH}_{3}$ gas flow rate $=2.2 \mathrm{~L} / \mathrm{min}$; influent ammonia/ $\mathrm{NH}_{3}$ gas concentrations 5 ppmv; GAC column length $=6 \mathrm{~cm}$; GAC bed dia. $6.35 \mathrm{~mm}$ ).

\section{Conclusions}

The application of GAC derived from date palm pits (DPP) agricultural waste for treating gaseous ammonia was studied along with the effect of influent gas flow rate, gas concentration, and GAC column length (bed depth) on to ammonia gas adsorption. Results show that DPP based GAC successfully treats gaseous ammonia under a varying set of process conditions. Respective findings indicate increased breakthrough/exhaustion time with a decrease in influent ammonia and increase in GAC bed depth. The broader breakthrough curves as noted in the present case for gaseous ammonia adsorption indicate comparatively larger length of mass transfer zone (MTZ), which suggests that longer GAC column lengths should be provided to avoid early breakthrough, for optimum real life applications. The efficiency of GAC produced from date palm pits was also compared with a commercial GAC and it showed the date palm pits based GAC to be having slightly higher breakthrough and exhaustion capacity. In conclusion, results from the present work show that the DPP based GAC can be successfully used to treat gaseous ammonia emissions with potential applications in many industries.

Funding: This research was funded by KACST through NSTIP Project \# 11-ENV1654-04.

Acknowledgments: The author is thankful to the King Fahd University of Petroleum and Minerals (KFUPM) for providing the necessary support for this work, the Civil and Environmental Engineering Department at KFUPM for providing the laboratory facilities, KACST for providing research grant through NSTIP Project \# 11-ENV1654-04, and the Deanship of Research at KFUPM for help with grant related matters. The author is also thankful to KFUPM Lab Technicians Monir for help during the GAC production phase, and Mariano (late) for help during the GAC characterization and also gas flow meter calibration. Help of other technicians for their prompt assistance during equipment/hardware setup is also appreciated. 
Conflicts of Interest: The author declares no conflict of interest.

\section{References}

1. Iyobe, T.; Asada, T.; Kawata, K.; Oikawa, K. Comparison of removal efficiencies for ammonia and amine gases between woody charcoal and activated carbon. J. Health Sci. 2004, 50, 148-153.

2. Yang, X.; Fraser, T.; Myat, D.; Smart, S.; Zhang, J.; Da Costa, J.C.D.; Liubinas, A.; Duke, M. A pervaporation study of ammonia solutions using molecular sieve silica membranes. Membranes 2014, 4, 40-54. [CrossRef] [PubMed]

3. Chou, M.-S.; Wang, C.-H. Treatment of Ammonia in Air Stream by Biotrickling Filter. Aerosol Air Qual. Res. 2007, 7, 17-32. [CrossRef]

4. Manakasettharn, S.; Takahashi, A.; Kawamoto, T.; Noda, K.; Sugiyama, Y.; Nakamura, T. Differences in NH3 gas adsorption behaviors of metal-hexacyanoferrate nanoparticles $\left(\mathrm{M}_{\mathrm{x}}\left[\mathrm{Fe}^{\mathrm{II}}(\mathrm{CN})_{6}\right]_{\mathrm{y}} \cdot \mathrm{zH}_{2} \mathrm{O}: \mathrm{M}=\mathrm{In}^{3+}, \mathrm{Fe}^{3+}\right.$, and $\mathrm{Mn}^{2+}$ ). J. Solid State Chem. 2019, 270, 112-117. [CrossRef]

5. Couvert, A.; Sanchez, C.; Laplanche, A.; Renner, C. Scrubbing intensification for sulphur and ammonia compounds removal. Chemosphere 2008, 70, 1510-1517. [CrossRef] [PubMed]

6. Zhao, Z.Q.; Bai, Z.H.; Winiwarter, W.; Kiesewetter, G.; Heyes, C.; Ma, L. Mitigating ammonia emission from agriculture reduces PM2.5 pollution in the Hai River Basin in China. Sci. Total Environ. 2017, 609, 1152-1160. [CrossRef] [PubMed]

7. Brown, M.S.; Cole, N.A.; Gruber, S.; Kube, J.; Teeter, J.S. Modeling and prediction accuracy of ammonia gas emissions from feedlot cattle. Appl. Anim. Sci. 2019, 35, 347-356. [CrossRef]

8. Sun, J.; Bai, M.; Shen, J.; Griffith, D.W.T.; Denmead, O.T.; Hill, J.; Lam, S.K.; Mosier, A.R.; Chen, D. Effects of lignite application on ammonia and nitrous oxide emissions from cattle pens. Sci. Total Environ. 2016, 565, 148-154. [CrossRef]

9. Agyarko-Mintah, E.; Cowie, A.; Van Zwieten, L.; Singh, B.P.; Smillie, R.; Harden, S.; Fornasier, F. Biochar lowers ammonia emission and improves nitrogen retention in poultry litter composting. Waste Manag. 2017, 61, 129-137. [CrossRef]

10. Drewry, J.L.; Choi, C.Y.; Powell, J.M.; Luck, B.D. Computational model of methane and ammonia emissions from dairy barns: Development and validation. Comput. Electron. Agric. 2018, 149, 80-89. [CrossRef]

11. Kanagawa, T.; Qi, H.W.; Okubo, T.; Tokura, N. Biological treatment of ammonia gas at high loading. Water Sci. Technol. 2004, 50, 283-290. [CrossRef]

12. Santos, C.; Goufo, P.; Fonseca, J.; Pereira, J.L.S.; Ferreira, L.; Coutinho, J.; Trindade, H. Effect of lignocellulosic and phenolic compounds on ammonia, nitric oxide and greenhouse gas emissions during composting. J. Clean. Prod. 2018, 171, 548-556. [CrossRef]

13. Oyarzun, P.; Alarcón, L.; Calabriano, G.; Bejarano, J.; Nuñez, D.; Ruiz-Tagle, N.; Urrutia, H. Trickling filter technology for biotreatment of nitrogenous compounds emitted in exhaust gases from fishmeal plants. J. Environ. Manag. 2019, 232, 165-170. [CrossRef]

14. Li, S.; Lang, J.; Zhou, Y.; Liang, X.; Chen, D.; Wei, P. Trends in ammonia emissions from light-duty gasoline vehicles in China, 1999-2017. Sci. Total Environ. 2020, 700, 134359. [CrossRef]

15. Petit, C.; Bandosz, T.J. Activated carbons modified with aluminium-zirconium polycations as adsorbents for ammonia. Microporous Mesoporous Mater. 2008, 114, 137-147. [CrossRef]

16. Lee, S.H.; Li, C.; Heber, A.J.; Ni, J.; Huang, H. Biofiltration of a mixture of ethylene, ammonia, n-butanol, and acetone gases. Bioresour. Technol. 2013, 127, 366-377. [CrossRef]

17. Ramírez, M.; Gómez, J.M.; Aroca, G.; Cantero, D. Removal of ammonia by immobilized Nitrosomonas europaea in a biotrickling filter packed with polyurethane foam. Chemosphere 2009, 74, 1385-1390. [CrossRef]

18. Maxima, M.; Hiraiwa, C.; Yamaguchi, A.; Fukunaga, A.; Awazu, T.; Ueda, T.; Nishizuka, K.; Mitsuhashi, F.; Kuramoto, T. Development of ammonia gas removal device. SEI Tech. Rev. 2012, 91-94.

19. Du, C.; Xue, Y.; Wu, Z.; Wu, Z. Microwave-assisted one-step preparation of macadamia nut shell-based activated carbon for efficient adsorption of Reactive Blue. New J. Chem. 2017, 41, 15373-15383. [CrossRef]

20. He, X.; Wu, Z.; Sun, Z.; Wei, X.; Wu, Z.; Ge, X.; Cravotto, G. A novel hybrid of $\beta$-cyclodextrin grafted onto activated carbon for rapid adsorption of naphthalene from aqueous solution. J. Mol. Liq. 2018, 255, 160-167. [CrossRef] 
21. Xue, Y.; Du, C.; Wu, Z.; Zhang, L. Relationship of cellulose and lignin contents in biomass to the structure and RB-19 adsorption behavior of activated carbon. New J. Chem. 2018, 42, 16493-16502. [CrossRef]

22. Wu, Z.; Wei, X.; Xue, Y.; He, X.; Yang, X. Removal effect of atrazine in co-solution with Bisphenol A or humic acid by different activated carbons. Materials 2018, 11, 2558. [CrossRef]

23. Faisal, A.A.H.; Al-Wakel, S.F.A.; Assi, H.A.; Naji, L.A.; Naushad, M. Waterworks sludge-filter sand permeable reactive barrier for removal of toxic lead ions from contaminated groundwater. J. Water Process Eng. 2020, 33, 101112. [CrossRef]

24. Naushad, M.; Alqadami, A.A.; AlOthman, Z.A.; Alsohaimi, I.H.; Algamdi, M.S.; Aldawsari, A.M. Adsorption kinetics, isotherm and reusability studies for the removal of cationic dye from aqueous medium using arginine modified activated carbon. J. Mol. Liq. 2019, 293, 111442. [CrossRef]

25. Guo, J.; $\mathrm{Xu}$, W.S.; Chen, Y.L.; Lua, A.C. Adsorption of $\mathrm{NH}_{3}$ onto activated carbon prepared from palm shells impregnated with $\mathrm{H}_{2} \mathrm{SO}_{4}$. J. Colloid Interface Sci. 2005, 281, 285-290. [CrossRef]

26. Gu, L.; Wang, D.; Deng, R.; Liu, H.; Ai, H. Effect of surface modification of activated carbon on its adsorption capacity for bromate. Desalin. Water Treat. 2013, 51, 2592-2601. [CrossRef]

27. Molina-Sabio, M.; Gonalves, M.; Rodríguez-Reinoso, F. Oxidation of activated carbon with aqueous solution of sodium dichloroisocyanurate: Effect on ammonia adsorption. Microporous Mesoporous Mater. 2011, 142, 577-584. [CrossRef]

28. Huang, C.C.; Li, H.S.; Chen, C.H. Effect of surface acidic oxides of activated carbon on adsorption of ammonia. J. Hazard. Mater. 2008, 159, 523-527. [CrossRef]

29. Bandosz, T.J.; Petit, C. On the reactive adsorption of ammonia on activated carbons modified by impregnation with inorganic compounds. J. Colloid Interface Sci. 2009, 338, 329-345. [CrossRef]

30. Park, S.J.; Jin, S.Y. Effect of ozone treatment on ammonia removal of activated carbons. J. Colloid Interface Sci. 2005, 286, 417-419. [CrossRef]

31. De la Cruz-Lovera, C.; Manzano-Agugliaro, F.; Salmerón-Manzano, E.; De la Cruz-Fernández, J.L.; Perea-Moreno, A.J. Date seeds (Phoenix dactylifera L.) valorization for boilers in the mediterranean climate. Sustainability 2019, 11, 711. [CrossRef]

32. Hai, A.; Bharath, G.; Babu, K.R.; Taher, H.; Naushad, M.; Banat, F. Date seeds biomass-derived activated carbon for efficient removal of $\mathrm{NaCl}$ from saline solution. Process Saf. Environ. Prot. 2019, 129, 103-111. [CrossRef]

33. Ahamad, T.; Naushad, M.; Alshehri, S.M. Ultra-fast spill oil recovery using a mesoporous lignin based nanocomposite prepared from date palm pits (Phoenix dactylifera L.). Int. J. Biol. Macromol. 2019, 130, $139-147$. [CrossRef] [PubMed]

34. Jamil, F.; Al-Muhtaseb, A.H.; Naushad, M.; Baawain, M.; Al-Mamun, A.; Saxena, S.K.; Viswanadham, N. Evaluation of synthesized green carbon catalyst from waste date pits for tertiary butylation of phenol. Arab. J. Chem. 2020, 13, 298-307. [CrossRef]

35. Naushad, M.; Khan, M.R.; AlOthman, Z.A.; AlSohaimi, I.; Rodriguez-Reinoso, F.; Turki, T.M.; Ali, R. Removal of $\mathrm{BrO}_{3}{ }^{-}$from drinking water samples using newly developed agricultural waste-based activated carbon and its determination by ultra-performance liquid chromatography-mass spectrometry. Environ. Sci. Pollut. Res. 2015, 22, 15853-15865. [CrossRef]

36. Jibril, B.; Houache, O.; Al-maamari, R.; Al-rashidi, B. Effects of $\mathrm{H}_{3} \mathrm{PO}_{4}$ and $\mathrm{KOH}$ in carbonization of lignocellulosic material. J. Anal. Appl. Pyrolysis 2008, 83, 151-156. [CrossRef]

37. Alhamed, Y.A. Adsorption kinetics and performance of packed bed adsorber for phenol removal using activated carbon from dates' stones. J. Hazard. Mater. 2009, 170, 763-770. [CrossRef]

38. Al-muhtaseb, S.A.; El-naas, M.H.; Abdallah, S. Removal of aluminum from aqueous solutions by adsorption on date-pit and BDH activated carbons. J. Hazard. Mater. 2008, 158, 300-307. [CrossRef]

39. Belhachemi, M.; Rios, R.V.R.A.; Addoun, F.; Silvestre-Albero, J.; Sepúlveda-Escribano, A.; Rodríguez-Reinoso, F. Preparation of activated carbon from date pits: Effect of the activation agent and liquid phase oxidation. J. Anal. Appl. Pyrolysis 2009, 86, 168-172. [CrossRef]

40. Bouchelta, C.; Salah, M.; Bertrand, O.; Bellat, J. Preparation and characterization of activated carbon from date stones by physical activation with steam. J. Anal. Appl. Pyrolysis 2008, 82, 70-77. [CrossRef]

41. Daifullah, A.A.M.; Girgis, B.S. Impact of surface characteristics of acti v ated carbon on adsorption of BTEX. Colloids Surf. A Physicochem. Eng. Asp. 2003, 214, 181-193. [CrossRef] 
42. El-naas, M.H.; Al-zuhair, S.; Alhaija, M.A. Reduction of COD in refinery wastewater through adsorption on date-pit activated carbon. J. Hazard. Mater. 2010, 173, 750-757. [CrossRef] [PubMed]

43. Girgis, B.S. Porosity development in activated carbons obtained from date pits under chemical activation with phosphoric acid. Microporous Mesoporous Mater. 2002, 52, 105-117. [CrossRef]

44. Hameed, B.H.; Salman, J.M.; Ahmad, A.L. Adsorption isotherm and kinetic modeling of 2, 4-D pesticide on activated carbon derived from date stones. J. Hazard. Mater. 2009, 163, 121-126. [CrossRef] [PubMed]

45. Merzougui, Z.; Addoun, F. Effect of oxidant treatment of date pit activated carbons application to the treatment of waters. Desalination 2008, 222, 394-403. [CrossRef]

46. Labaran, B.A.; Vohra, M.S. Application of activated carbon produced from phosphoric acid-based chemical activation of oil fly ash for the removal of some charged aqueous phase dyes: Role of surface charge, adsorption kinetics, and modeling. Desalin. Water Treat. 2016, 57, 16034-16052. [CrossRef]

47. Vohra, M.S. Adsorption-Based Removal of Gas-Phase Benzene Using Granular Activated Carbon (GAC) Produced from Date Palm Pits. Arab. J. Sci. Eng. 2015, 40, 3007-3017. [CrossRef]

48. Le Leuch, L.M.; Bandosz, T.J. The role of water and surface acidity on the reactive adsorption of ammonia on modified activated carbons. Carbon 2007, 45, 568-578. [CrossRef]

49. Fortier, H.; Westreich, P.; Selig, S.; Zelenietz, C.; Dahn, J.R. Ammonia, cyclohexane, nitrogen and water adsorption capacities of an activated carbon impregnated with increasing amounts of $\mathrm{ZnCl}$, and designed to chemisorb gaseous $\mathrm{NH}_{3}$ from an air stream. J. Colloid Interface Sci. 2008, 320, 423-435. [CrossRef]

50. Lim, E.; Yao, J. Modeling and simulation of the polymeric nanocapsule formation process. IFAC Proc. Vol. 2009, 7, 405-410.

51. Held, A.; Pratt, D.W. Ammonia as a Hydrogen Bond Donor and Acceptor in the Gas Phase. Structures of 2-Pyridone-NH3 and 2-Pyridone-(NH3)2 in Their S0 and S1 Electronic States. J. Am. Chem. Soc. 1993, 115, 9718-9723. [CrossRef]

52. Weng, Y.; Qiu, S.; Ma, L.; Liu, Q.; Ding, M.; Zhang, Q.; Zhang, Q.; Wang, T. Jet-Fuel range hydrocarbons from biomass-derived sorbitol over Ni-HZSM-5/SBA-15 catalyst. Catalysts 2015, 5, 2147-2160. [CrossRef]

(C) 2020 by the author. Licensee MDPI, Basel, Switzerland. This article is an open access article distributed under the terms and conditions of the Creative Commons Attribution (CC BY) license (http://creativecommons.org/licenses/by/4.0/). 